\title{
PEMBELAJARAN BERBAGAI JENIS TEKS BERBAHASAINGGRIS (ENGLISH GENRES) MELALUI OBSERVATIONAL LEARNING IMPLEMENTASI DAN PERMASALAHAN
}

\author{
Lasito \\ Pendidikan Bahasa dan Sastra Inggris Universitas Negeri Jakarta
}

\begin{abstract}
Abstrak
Penelitian ini membahas tentang pelaksanaan pembelajaran melalui pengamatan (observational learning) dalam pengajaran berbagai jenis teks dalam bahasa Inggris (English genres) yang dilakukan di salah satu sekolah menengah atas di Jakarta. Menggunakan metode ethnografi melalui pengamatan selama satu semester, penelitian ini menunjukkan berbagai masalah penting yang dihadapi oleh guru dan siswa dalam usahanya menerapkan pembelajaran berbasis pengamatan. Pertama, keterbatasan teks yang dimiliki guru yang dijadikan sebagai model. Kedua kurangnya paparan terhadap teks yang dijadikan model menyebabkan siswa tidak memiliki informasi yang kaya akan variasi teks sejenis. Ketiga adanya penolakan siswa terhadap metode observational learning. Siswa lebih nyaman dengan guru menerangkan dan memberikan latihan (teacher-centered) dibandingkan siswa sendiri harus mengamati dan bereksplorasi dengan teks.
\end{abstract}

Kata Kunci: Jenis teks bahasa inggris, pembelajaran melalui pengamatan, pembelajaran bahasa

\begin{abstract}
This research discusses about the implementation of learning through observation (observational learning) in the teaching of various types of texts in English (English genres) are performed in one high school in Jakarta. Using ethnographic methods through observation during one semester, this study shows the important issues faced by teachers and students in their efforts to apply the learning-based observations. First, teachers have limited text that is used as a model. Both the lack of exposure to the text which is used as a model causes the student does not have a rich variety of information similar text. Third student rejection of the methods of observational learning. Students are more comfortable with the teacher to explain and provide training (teacher-centered) than the students themselves have to observe and explore the text.
\end{abstract}

Keywords: English genre, observational learning, language learning

\section{PENDAHULUAN}

Kurikulum Berbasis Kompetensi yang mendasari lahirnya Kurikulum 2013 didasarkan atas penguasaan berbagai jenis teks fungsional berbahasa Inggris (English genres). Dalam perspektif genre, semua produk bahasa dimana bahasa menjadi sentralnya dapat disebut sebagai sebuah teks. Bergagai jenis teks yang memiliki kesamaan karakteristik - tujuan penulisan, bagaimana teks disusun, dan bahasa yang digunakan didalamnya - dapat dikelompokkan kedalam satu jenis teks (genre). Penguasaan berbagai jenis teks fungsional berbahasa Inggris (English genres) ini kemudian diintegrasikan kedalam Kompetensi Inti (KI) dan Kompetensi Dasar (KD). 
Keberhasilan dari pembelajaran berbasis teks (genres) ini terletak pada sejauh mana keterlibatan siswa terhadap jenis-jenis teks yang akan dipelajari. Sehingga kegiatan 'modelling' berperan penting dalam proses pembelajaran. Hal ini juga ditunjukkan dalam berbagai laporan, seperti The Australian Disadvantage Education Project dan The Sydney School Project, dimana kegiatan modeling menjadi kegiatan utama pembelajaran dan juga kegiatan konstruksi bersama (joint construction). Keberhasilan pengajaran berbasis genre di Australia ini ditunjang oleh fakta dimana di Australia bahasa Inggris merupakan bahasa pertama dan bahasa kedua yang memungkinkan siswa memiliki paparan bahasa \{language exposure) yang berlimpah. Selain itu, untuk konteks bahasa Inggris sebagai bahasa pertama atau kedua, keberhasilan pemelajaran bahasa Inggris bukan ditentukan oleh kegiatan persekolahan namun oleh banyaknya model yang diamati oleh siswa dalam kehidupan sehari-hari.

Dengan segala keterbatasan paparan bahasa Inggris (language exposure) yang ada di Indonesia, penelitian ini bertujuan untuk menerapkan pembelajaran berbasis observasi (observational learning) untuk memaksimalkan kegiatan modeling serta kendala yang dihadapi saat penerapan observational learning dalam mengajarkan berbagai jenis teks fungsional bahasa Inggris (English genres).

\section{Genre di Sekolah}

Konsep genre diilhami dari the Sydney School Project yang difokuskan kepada (i) genre yang diperlukan oleh siswa untuk belajar membaca dan menulis, (ii) genre yang biasanya dipakai oleh guru dalam membelajarkan siswa (Rose \& Martin in press). The Sydney Schoolmendefinisikan genre sebagai 'staged goal-oriented social processes'. Genre bersifat 'goal oriented karena berusaha untuk mengungkap tujuan sosial dari teks-teks yang ada. Memiliki tahapan 'staged karena biasanya diperlukan lebih dari satu langkah (tahapan) guna mencapai tujuan sosialnya. Genre muncul di masyarakat untuk mengakomodasi kepentingan (tujuan) anggota masyarakat, sehingga tahapan-tahapan yang dilaluipun biasanya bisa diprediksi.

Genre dalam kaitannya dengan kegiatan persekolahan, beberapa diantaranya adalah bertujuan untuk menjelaskan phenomena alam dan sosial, mengklasifikasikan objek dan mendeskripsikannya, membuat dan memahami instruksi, menceritakan peristiwa atau kejadian, dll. Tujuan-tujuan tersebut biasanya dilakukan dalam kegiatan membaca dan menulis. The Sydney School riset berhasil merumuskan berbagai teks dengan tujuan seperti tersebut di atas ternyata terbentuk dari beberapa tahapan yang konsisten sehingga hal tersebut membedakan jenis teks satu terhadap yang lainnya (Rose, 2008). Oleh karenanya, berbagai macam tujuan teks dan tahapan-tahapan yang digunakan diberi beberapa label (nama), sehingga guru dapat mengajarkannya secara eksplisit kepada siswa. Berikut adalah tabel yang memuat beberapa label (nama) genre tulis di sekolah.

\section{Tabel. 1. Genre Tulis Disekolah}

\begin{tabular}{|l|l|l|}
\hline Genre & Purpose & Stages \\
\hline Recount & Recounting events & $\begin{array}{l}\text { Orientation } \\
\text { Record of events }\end{array}$ \\
\hline Narrative & Resolving a complication & Orientation \\
\hline
\end{tabular}




\begin{tabular}{|l|l|l|}
\hline & & $\begin{array}{l}\text { Complication } \\
\text { Evaluation } \\
\text { Resolution }\end{array}$ \\
\hline Report & $\begin{array}{l}\text { Classifying and describing } \\
\text { general things }\end{array}$ & $\begin{array}{l}\text { Classification } \\
\text { Description }\end{array}$ \\
\hline Explanation & Explaining sequences of events & $\begin{array}{l}\text { Phenomenon } \\
\text { Explanation }\end{array}$ \\
\hline Procedure & How to do an activity & $\begin{array}{l}\text { Purpose } \\
\text { Equipment } \\
\text { Steps }\end{array}$ \\
\hline Exposition & Arguing for a point of view & $\begin{array}{l}\text { Thesis } \\
\text { Argumentation } \\
\text { Reiteration }\end{array}$ \\
\hline
\end{tabular}

(Dari Martin \& Rose, 2012)

Perlu diingat bahwa tahapan-tahapan untuk mencapai tujuan sosial dari teks-teks tersebut tidak bersifat rigit dan mudak, melainkan generik sesuai dengan tujuan tertentu yangingin dicapai oleh suatu teks (Martin \& Rose, 2008; Rose, 2006). Dalam konteks tertentu mungkin akan mengalami pengulangan tahapan atau penambahan. Sebagai contoh dalam suatu genre narrative, ada kemungkinan teks ini dikembangkan ke dalam beberapa complications dan resolutions. Begitu pula deskripsi pada genre report tentang binatang, bisa jadi tahapan description dikembangkan dalam pelbagai bagian seperti deskripsi tentang habitat, jenisnya, mekanisme gerak, cara bereproduksi, dll.

\section{Belajar Modeling Melalui Observational Learning}

Bandura (2005) menyatakan bahwa proses belajar dimulai dengan mengalami model secara sosial (social modeling experiences) dan berkembang melalui kegiatan meniru (emulation) sampai akhirnya seseorang memiliki kendali tentang apa yang dipelajari (self-eficacy). Proses ini menyiratkan makna bahwa tahapan pertama dalam suatu proses belajar adalah tahap observasi (observation level), dalam tahap tersebut siswa akan mengamati seorang model (contoh) yang akan melakukan tindakan (perilaku) yang ingin dipelajari. Saat siswa mulai mencoba meniru -secara terbimbing - untuk mengadopsi perilaku tersebut, siswa mulai bergeser menuju tahapan meniru (emulation level). Tahapan yang ketiga adalah self-controlled level, yaitu siswa mulai berlatih melakukan tindakan secara mandiri, tetapi masih dalam setting yang terstruktur. The self regulated level adalah tahapan terakhir dalam proses belajar dimana siswa dapat menyesuaikan tindakan terhadap kondisi yang berbeda.

Namun demikian, tidak semua perilaku/ tindakan yang diamati dapat dipelajari dengan baik. Dua faktor utama, yaitu model dan siswa juga berperan penting untuk suksesnya belajar sosial (social learning). Ada beberapa syarat dan langkah-langkah yang harus diperhatikan untuk pelaksanaan kegiatan belajar melalui pengamatan (observational learning) dan pemodelan (modeling) ini: attention-retention-reproduction-motivation (Bandura, 1977) seperti ditunjukkan dibawah ini:

a. Perhatian (Attention). Dalam belajar, seseorang perlu memusatkan perhatian. Segala sesuatu yang dapat memecah perhatian akan mengganggu kegiatan belajar dalam observational learning. 
Biasanya semakin model itu menarik, semakin perhatian seseorang terhadap model yang diamatinya.

b. Menyimpan (Retention). Kemampuan untuk menyimpan informasi sangat penting dalam proses belajar. Kemampuan untuk mengingat informasi dan melakukan tindakan berdasarkan informasi yang telah dipelajari menjadi factor yang sangat krusial.

c. Melakukan/Membuat (Reproduction). Saat siswa sudah dapat memusatkan perhatian, menyimpaninformasi dan menggunakannya dengan baik, tibalah saatnya bagi siswa untuk melakukan tindakan. Semakin sering dilakukan (dipraktekkan), akan semakin baik kemampuan seseorang dalam hal yang telah dipelajari itu.

d. Motivasi (motivation). Akhirnya, observational learning menjadi lebih solid saat seseorang dapat menggunakan pengalaman belajarnya atau termotivasi oleh pengalaman orang lain dalam mempelajari hal-hal yang baru.

\section{METODOLOGI}

\section{Partisipan}

Penelitian ini melibatkan 36 siswa kelas XI yang terdiri dari 16 siswa dan 20 siswi pada sekolah menegah atas di Jakarta. Selain itu penelitian ini juga melibatkan guru dan dua orang kolaborator, yaitu seorang pengamat (observer) dan seorang pembimbing.

\section{Data}

Data berupa rekaman proses pembelajaran, diari guru, catatan umpan balik (feedback) dari siswa, catatan lapangan (field note) pengamat, serta catatan dari pembimbing.

\section{Desain Penelitian}

Dari kajian teori yang sudah dibahas pada bagian sebelumnya, penulis mengelaborasi tahapan-tahapan tersebut (Attention - Retention - Reproduction) ke dalam langkah-langkah pembelajaran seperti terlihat dibawah ini.

1. Perhatian (Attention). Karena yang menjadi bahan pelajaran adalah genre, maka perhatian ditujukan pada tiga unsur utama pembentuk genre, yaitu social purpose of the text, the generic structure, dan the language features.

1.a. Attention to social purpose of the text

- Brainstorming tentang keberadaan teks dan membandingkannya dengan yang ada di budaya siswa.

- Memprediksi isi teks yang akan dipelajari

- Mengidentifikasi elemen yang berhubungan dengan teks kenapa teks tersebut ditulis, siapa yang berkepentingan, kapan teks dibuat, dll

l.b. Attention to the generic structure of the text

- Memaksimalkan media (LCD, video, TV, dll) untuk memperkenalkan/ menampilkan contoh teks supaya lebih menarik dan memotvasi siswa.

- Mendekonstruksi teks (bagaimana teks terbentuk).

- Membandingkan dengan beberapa contoh lainnya.

- Mengklasifikasikan beberapa teks kedalam teks-teks yang memiliki kesamaan dan yang tidak memiliki kesamaan.

I.c. Attention to the language features of the text

- Cloze activity - memfokuskan perhatian pada fitur bahasa 
tertentu (seperti: verb forms, connectives, time signals, dll).

- Menjodohkan ( missal: kata ganti (reference) dengan partisipannya, klausa dengan terjemahannya, dll)

- Memberikan penggalan teks kalimat atau kata kunci - untuk dihubungkan dengan fitur bahasa yang sesuai (seperti: modal verbs, conjuctions, connectives, dll).

2. Menyimpan (Retention)

- Melafalkan kata dengan baik dan mengingat artinya

- Menyalin teks (menyalik langsung dari sumber ke dalam buku, atau mendiktekan teks untuk ditulis oleh siswa)

- Membuat draft dan mengedit teks

- Mengidentifikasi tahapan-tahapan teks dan fitur bahasa yang digunakan.

- Mencari teks sejenis dari berbagai sumber (Koran, majalah, buku cerita, manual, dll)

3. Mencoba/Membuat (Reproduction)

- Menulis teks berdasarkan gambar dan kata kunci

Melanjutkan tulisan dari prolog yang sudah diberikan.

- Melaporkan/menceritakan suatu teks menggunakan bantuan gambar atau kata kunci

- Membuat teks secara mandiri tanpa bantuan (gambar atau kata kunci).

\section{HASIL PENELITIAN DAN PEMBAHASAN}

Penerapan observational learning untuk pengajaran berbagai teks fungsional bahasa Inggris (English genres) bertujuan untuk memaksimalkan hasil belajar siswa. Namun demikian, segala sesuatu yang baru, seperti observational learning, ternyata juga tidak mudah untuk diterapkan di kelas. Banyak kendala yang menjadi penghambat penerapan metode tersebut. Berikut akan dibahas temuan sehubungan dengan penerapan observational learning untuk mengajarkan berbagai teks fungsional bahasa Inggris (English genres) di kelas.

\section{Keterbatasan Teks Untuk Model}

Kunci sukses observational learning terletak dari jumlah dan kualitas teks yang di jadikan model. Dengan keterbatasan guru, waktu dan materi, guru tidak dapat memberikan paparan teks yang memadahi. Guru hanya bisa memberikan contoh dua teks untuk masing-masing genre. Seperti dikutip dalam diari guru sebagai berikut:

$"$ it is difficult to find recount texts. I only had two and they were not authentic enough. I took them from text books"

(Guru, May, 10)

Oleh pembimbing, guru disarankan untuk menugaskan siswa untuk berkontribusi mencari teks, namun demikian banyak siswa yang mengeluh karena susahnya mencari contoh teks. Hal itu juga dicatat dalam diari guru sebagai berikut:

" Many students complained that it was difficult to find the texts" (Guru, March, 22)

Kesulitan yang dialami oleh guru dan siswa ini dapat dimaklumi mengingat keterbatasan sumber/materi ajar berbahasa Inggris yang ada di Indonesia. Sekali lagi hal ini berkenaan dengan status sosial dan aspek budaya yang menempatkan bahasa Inggris sebagai bahasa asing. Konsekuensi logisnya adalah minimnya paparan bahasa baik lisan dan tulisan dimasyarakat. 


\section{Siswa Tidak Memahami Variasi Dari Teks Sejenis}

Seperti telah disampaikan diatas, keterbatasan teks yang dimiliki guru menyebabkan guru tidak dapat memberikan paparan model (teks) yang bervariatif, sehingga siswa menganggap kalau generic structure suatu teks itu bersifat paten dan tidak berubah. Hal ini terlihat saat siswa mengerjakan latihan mendekonstruksi teks naratif (cerita). Dalam kegiatan tersebut, banyak siswa memberi label bagian sesuai dengan contoh yang diberikan guru yaitu, orientation - complication evaluation - resolution. Padahal untuk kasus tertentu ada beberapa cerita yang memiliki beberapa konflik (complication). Hal ini juga terekam dalam catatan diari guru sebagai berikut:

" beberapa hasil pekerjaan anak-anak tidak sesuai dengan urutan ceritanya"

(Guru, April 26)

Dari konsultasi dengan pembimbing, beliau juga menganggap bahwa saat guru tidak memberikan model yang cukup, hal ini akan menjadikan murid menjadi tidak siap saat menghadapi teks yang sebenarnya dilingkungannya. Mereka akan mengalami kebingungan dan tidak dapat memahami teks nyata yang ada disekitarnya. Hal ini seperti pernyataan pembimbing sebagai berikut:

" Teacher withdrew students from reality. What they see outside is not the same with what they've learnt in the classroom"

(Pembimbing, May, 11)

Seperti telah disarankan oleh Martin dan Rose (2008) dan Rose (2006) bahwa dalam satu genre ada kemungkinan dikembangakan dengan cara mengulang beberapa bagian dari tahapan tertentu. Hal ini dibuktikan dalam penelitian ini bahwa benar ada satu teks (narrative) yang memikiki pengulangan konflik \{complication) sampai beberapa kali, bahkan ada satu teks yang memulai ceritanya dengan konflik (alurflash back).

\section{Penolakan Dari Siswa}

Untuk mengubah suatu kebiassaan memang tidaklah mudah, begitu pula saat penerapan observational learning ini. Sekali lagi, kunci keberhasilan observational learning terletak dari paparan teks yang dijadikan model. Oleh karena itu, guru berusaha memberikan beberapa contoh dan dibahas dalam beberapa kali pertemuan. Namun demikian, siswa berfikiran sebaliknya. Mereka merasa bosan dengan kegiatan dan materi pelajaran yang sama. Hal ini ditunjukkan dari komentar beberapa orang siswa:

"Pelajarannya tentang itu-itu melulu" (Siswa, 4)

" Kalau ngajar satu materi, jangan itu-itu mulu yang dipelajarin. Bosing sir!" (Siswa, 5)

" ...Kalau belajarnya seperti it uterusterusan saya jadi bete. Bukan hanya saya saja, tetapi yang lainnya juga" (Siswa, 9)

Selain siswa cepat bosan, mereka juga merasa dengan metode observational learning ini mereka merasa 'tidak belajar' sesuatu ilmu yang baru. Selama ini siswa terbiasa dengan guru menerangkan, memberi contoh dan mengerjakan latihan (teacher centered), jadi saat siswa harus aktif mengamati model (teks) mereka merasa itu bukan rutinitas mereka saat belajar. Hal ini terlihat dari beberapa komentar siswa sebagai berikut. 
"... ngajarnya sering gak focus ke satu pelajaran saja, udah gitu gak pernah dijelasin" (Siswa, 7)

"Pelajarannya sih sebenarnya enak, tapi ngajarnya gak jelas" (Siswa, 17)

" Susah dimengerti, ngajarnya yang jelas dong!"

(Siswa, 28)

Beberapa pernyataan siswa diatas menyiratkan betapa mereka sangat tidak nyaman dengan observational learning. Mereka lebih nyaman dengan metode guru yang selama ini mereka jumpai (Presentation, Practice, Production). Padahal, metode PPP ini sudah mendapat banyak kritikan dari para ahli karena metode ini tidak membuat siswa menggunakan bahasa Inggris secara natural (Johnson, 1982; Byrne, 1986; Woodward, 1993; Scrivener, 1994 dalam Harmer, 2001).

\section{SIMPULAN}

Menerima suatu perubahan tidaklah semudah membalikkan telapak tangan. Begitu pula saat penerapan observational learning untuk pengajaran teks fungsional bahasa Inggris (English genres). Dalam penerapannya, ditemukan beberapa masalah yang mengemuka diantaranya keterbatasan teks untuk model, siswa tidak memahami variasi dari teks sejenis, dan adanya penolakan dari siswa terhadap penerapan observational learning.

Sejatinya observasional learning merupakan metode yang sangat baik karena membuat siswa belajar secara natural melalui pengamatan terhadap model. Namun perlu diperhatikan pula bahwa kondisi sosial, budaya, dan politik yang menempatkan bahasa Inggris sebagai bahasa asing sedikit banyak berpengaruh pada paparan bahasa baik lisan dan tulis yang bisa dijadikan sebagai model. Sehingga perlu dipikirkan cara bagaimana untuk menyiasati pengadaan model yang cukup untuk dijadikan contoh dalam pembelajaran berbasis genre.

\section{DAFTAR PUSTAKA}

Bandura, A. (1977). Social learning theory. New York. General Learning Press

Bandura, A. (1986). Social foundadons of thought and action: a social-cognitive theory. Upper Saddle River, NJ: Prentice Hall.

Bandura, A. (2005). The evolution of social cognitive theory. In K. smith \& M. Hitt (Eds.), Great minds in management (p.935). Oxford: Oxford University Press.

Harmer,J. (2001). The practice of English Language Teaching. England, longman

Martin, J.R. \& D. Rose. (2008). Genre relations: mapping culture, London: Equinox.

Martin, J. R. \& D. rose. (2012).Genres and texts: living in the real world. Indonesian journal of Systemic Functional Linguistics 1(1), 1-21.

Rose, D. \& J.R. Martin (in press) Reading to learn: learning to write. London: Equinox.

Rose, D. (2006).Reading genre: a new wave of analysis. Linguistics and the Human Sciences 2 (2), 185-204.

Rose, D. (2008). Writing as linguistic mastery: the development of genre-based literacy

pedagogy R. Beard, D. Myhill, J. Rilley \& M. Nystrand (eds.) Handbook of Writing Development. London: Sage, 151-166 